\title{
Anemia in children with chronic kidney disease
}

\author{
Susan M. Koshy • Denis F. Geary
}

Received: 10 July 2006 /Revised: 24 October 2006 / Accepted: 26 October 2006 / Published online: 24 January 2007

(C) IPNA 2007

\begin{abstract}
Anemia is a common feature of chronic kidney disease, but the management of anemia in children is complex. Erythropoietin and supplemental iron are used to maintain hemoglobin levels. The National Kidney Foundation-Kidney Disease Outcomes Quality Initiative (NKFKDOQI) clinical practice guidelines for the management of anemia specifically in children were recently published. Pediatric nephrologists are encouraged to use current clinical practice guidelines and best evidence in conjunction with their clinical experience to optimally manage patients with anemia.
\end{abstract}

Keywords Chronic kidney disease · Erythropoietin . Hemoglobin · Iron · Pediatric

\section{Introduction}

Anemia is a universal problem among children with chronic kidney disease (CKD). Lower levels of glomerular filtration rate (GFR) are associated with lower levels of hemoglobin, and in adults the latter is most pronounced when the GFR falls below $60 \mathrm{~mL} / \mathrm{min}$ per $1.73 \mathrm{~m}^{2}$ [1]. In children, the relationship between GFR and anemia is less clear. However, treatment of anemia in both adults and children has improved dramatically with the advent of regular erythropoietin (EPO) and iron therapy, and it has become possible to avoid routine transfusions to maintain a patient's

S. M. Koshy $\cdot$ D. F. Geary $(\bowtie)$

Division of Nephrology, Department of Pediatrics,

The Hospital for Sick Children,

555 University Avenue,

M5G 1X8 Toronto, Canada

e-mail: denis.geary@sickkids.ca hemoglobin. As well, the many studies performed in adults and relatively fewer studies carried out in children have demonstrated that improved hemoglobin levels are associated with benefits in quality of life, cognitive function, exercise capacity and cardiovascular function [2-4].

Despite the wide availability of erythropoietic stimulating agents and supplemental iron preparations, anemia remains highly prevalent in the pediatric CKD population. Using data from the United States Renal Data System, Chavers et al. demonstrated that the hemoglobin values in pediatric chronic hemodialysis (HD) and peritoneal dialysis (PD) patients treated with recombinant human EPO were still lower than those of adult patients. These researchers found that mean annual hemoglobin values of less than $11 \mathrm{~g} / \mathrm{dL}$ were present in $54.1 \%$ patient years among pediatric HD patients compared to $39.8 \%$ patient years in their adult counterparts. For PD patients, anemia was present in $69.5 \%$ patient years among pediatric patients and $55.1 \%$ among adult patients [5]. A recent Canadian study investigated the prevalence of complications according to stage of CKD in children. Overall, anemia was present in $36.6 \%$ of all patients with kidney disease. Anemia was defined as all those who were treated with iron or darbepoetin and those with a hemoglobin count of $<120 \mathrm{~g} / \mathrm{L}$. The prevalence of anemia increased from $31 \%$ in those with stage 1 CKD to $93.3 \%$ among those with CKD stages 4 plus 5 [6].

Management guidelines for anemia in pediatric CKD patients have been developed from reported studies in both adults and children, from clinical experience and from expert opinion. The revised National Kidney FoundationKidney Disease Outcomes Quality Initiative (NKFKDOQI) clinical practice guidelines for the management of anemia specifically for children have been recently 
published [7]. The objective of this article is to provide a review of the diagnosis, etiology, investigations, patient outcomes and treatment of anemia in children with CKD.

\section{Diagnosis}

According to the classical definition of anemia in Nelson's Textbook of Pediatrics, 'anemia is defined as a reduction of the red blood cell volume or hemoglobin below the range of values for healthy persons' [8]. However, a great deal of controversy surrounds the definition of normal values of hemoglobin in children with CKD. Normal values adopted for children with CKD are based on observations of values in healthy children, the ranges of which are $120 \mathrm{~g} / \mathrm{L}$ (range: 95-145 g/L) in 3-month-old children, $120 \mathrm{~g} / \mathrm{L}$ (range: 105$140 \mathrm{~g} / \mathrm{L}$ ) in 6-month-old to 6-year-old children and $130 \mathrm{~g} / \mathrm{L}$ (range: $110-160 \mathrm{~g} / \mathrm{L}$ ) in children aged $7-12$ years [8]. Some studies also cite the World Health Organization definition of anemia where children aged 6 months to 6 years are anemic if the hemoglobin count is less than $110 \mathrm{~g} / \mathrm{L}$ and children aged 6-14 years are considered anemic if it is less than $120 \mathrm{~g} / \mathrm{L}$ [9]. The new NKF-KDOQI clinical practice guidelines use NHANES-III reference data to cite normative values in children [7]. NHANES-III is the third U.S. National Health and Nutrition Examination Survey database, and the report on hematological and iron-related indices provides means, standard errors and percentile distributions for laboratory values of hematological and iron indices for the United States population in 1988-1994 [10] (Tables 1, 2). The NKF-KDOQI guidelines recommend the initiation of a work-up for anemia if the hemoglobin value is less than the fifth percentile for age and sex [7].

Earlier NKF-KDOQI guidelines suggested threshold values for hematocrit as well as hemoglobin to guide the initiation of work-up for anemia. However, a patient's hematocrit is highly vulnerable to volume status, hyperglycemia and the timing of sampling and, therefore, it has

Table 1 Hemoglobin levels from NHANES-III for boys of all race/ ethnic groups according to age [10]

\begin{tabular}{llll}
\hline $\begin{array}{l}\text { Age range } \\
\text { (years) }\end{array}$ & $\begin{array}{l}\text { Mean hemolobin } \\
\text { level }(\mathrm{g} / \mathrm{L})\end{array}$ & $\begin{array}{l}\text { Standard } \\
\text { deviation }\end{array}$ & $\begin{array}{l}\text { 5th } \\
\text { Percentile }\end{array}$ \\
\hline 1 and over & 146.7 & 13.9 & 121.0 \\
$1-2$ & 120.1 & 8.2 & 107.0 \\
$3-5$ & 123.5 & 7.7 & 111.5 \\
$6-8$ & 128.8 & 8.0 & 115.1 \\
$9-11$ & 132.8 & 8.4 & 119.6 \\
$12-14$ & 141.4 & 10.8 & 124.1 \\
$15-19$ & 150.7 & 10.3 & 134.6 \\
\hline
\end{tabular}

Table 2 Hemoglobin levels from NHANES-III for girls of all race/ ethnic groups according to age [10]

\begin{tabular}{llll}
\hline $\begin{array}{l}\text { Age range } \\
\text { years) }\end{array}$ & $\begin{array}{l}\text { Mean hemolobin } \\
\text { level }(\mathrm{g} / \mathrm{L})\end{array}$ & $\begin{array}{l}\text { Standard } \\
\text { deviation }\end{array}$ & $\begin{array}{l}\text { 5th } \\
\text { Percentile }\end{array}$ \\
\hline 1 and over & 131.9 & 11.0 & 114.0 \\
$1-2$ & 120.2 & 8.0 & 108.0 \\
$3-5$ & 123.9 & 7.7 & 111.1 \\
$6-8$ & 128.2 & 7.7 & 115.0 \\
$9-11$ & 131.0 & 7.8 & 118.5 \\
$12-14$ & 132.9 & 10.0 & 117.0 \\
$15-19$ & 131.5 & 10.0 & 114.6 \\
\hline
\end{tabular}

become a less useful measure of anemia. It is also affected by the technological approach used at different laboratories.

\section{Etiology}

There are several causes of anemia in patients with CKD. EPO deficiency and iron deficiency are the leading causes regardless of dialysis status. Other causes contributing to anemia in CKD patients are inflammation, chronic blood loss, hyperparathyroidism, aluminum toxicity, hemoglobinopathies, vitamin deficiencies (B12 and folate), hemolysis and adverse effects of cytotoxic or immunosuppressive drugs and angiotensin converting enzyme inhibitors.

\section{Lack of erythropoietin}

The major cause of anemia in patients with CKD is lack of EPO synthesis in the diseased kidneys [11, 12]. EPO is a $30.4-\mathrm{kDa}$ glycoprotein containing $40 \%$ carbohydrate that is encoded by a gene identified and cloned in 1985 [13, 14]. The liver is the primary source of EPO production in the fetus, but after birth, a group of peritubular interstitial cells in the kidney take over this function, becoming the major sites of EPO production $[15,16]$. In response to reduced oxygen supply, EPO production is increased by a hypoxiainducible factor transcription factor that controls the EPO gene [15]. A reduced GFR may cause decreased sodium reabsorption in the tubules and because sodium re-absorption is the main determinant of energy consumption in the nephron, this may lead to a relative excess of oxygen, signaling a decrease in EPO production [17]. The protein portion of EPO binds to an erythroid progenitor cell surface receptor to regulate bone marrow erythroid cell proliferation, differentiation and survival [15]. As might be expected, in renal failure the control of EPO is deranged, becoming the single largest factor contributing to the anemia of chronic renal disease. In 1987, therapy with recombinant human EPO was shown to correct the anemia resulting from chronic renal failure in dialysis patients [12]. 
Iron deficiency

The second major cause of anemia in kidney disease is iron deficiency. There is an 'absolute' and 'functional' iron deficiency that can be corrected with aggressive iron replacement therapy in CKD. Absolute iron deficiency occurs when iron stores are depleted as a result of loss or decreased intake; however, functional deficiency occurs when there is a need for a greater amount of iron to support hemoglobin synthesis than can be released from iron stores [18].

Iron deficiency is common in HD patients due to chronic blood loss from repeated blood sampling, surgical interventions, blood loss through the use of dialyzers and tubing and shortened red blood cell lifespan [19]. Daily blood loss in pre-dialysis pediatric CKD patients is approximately $6 \mathrm{~mL} / \mathrm{m}^{2}$. In contrast, HD patients have gastrointestinal blood losses estimated to be $11 \mathrm{~mL} / \mathrm{m}^{2}$ daily, and there is a further HD-associated blood loss of $8 \mathrm{~mL} / \mathrm{m}^{2}$ per treatment [20]. Treatment with EPO also demands more iron for hemoglobin synthesis, and iron supplementation can decrease the required dose of EPO in both adults and children $[21,22]$.

Iron is absorbed mainly in the duodenum, but it is also recycled from old red blood cells. It circulates in the plasma bound to transferrin. In the body, iron is mostly bound to hemoglobin and cells of the reticuloendothelial system and hepatocytes. A small amount is also stored in muscle fibers and other tissues. Transferrin with iron binds to erythroid cells and is endocytosed into the red cells for the production of heme. In non-red blood cells iron is stored as ferritin or hemosiderin [23]. Patients with CKD present with disturbances in the iron metabolic pathway. As transferrin levels are reduced to one half or one third that of normal levels in patients with kidney disease, iron transport to the bone marrow for the production of red cells is decreased [18]. In addition, there is an impaired release of stored iron from macrophages and hepatocytes to transferrin in patients with kidney disease. This will manifest clinically as high ferritin levels due to the impaired release of stored iron [18].

\section{Other causes}

There are numerous other causes of anemia among CKD patients, some of which may cause hyporesponsiveness to EPO and iron. For example, the presence of inflammation contributes to anemia [24] also, ferritin levels tend to be increased in the presence of inflammation, thereby complicating the diagnosis of iron deficiency. Inflammatory mediators such as interleukin-6, interleukin-1 and tumor necrosis factor- $\alpha$ interfere with the maturation of red cell precursors in patients with CKD [25]. In addition, severe secondary hyperparathyroidism is known to cause myelofibrosis that may obliterate bone marrow, leading to anemia [26]. In addition, aluminum toxicity due to chronic hemodialysis is associated with a microcytic anemia in HD patients [27]. One must also look for coexisting hemoglobinopathies, such as sickle cell disease and $\beta$ thalassemia, depending on the ethnic background of the patient as these microcytic anemias can also complicate the diagnosis of iron deficiency [28, 29]. Furthermore, poor nutritional intake will lead to vitamin B12 and folate deficiencies. Finally, the use of cytotoxic and immunosuppressive drugs, such as cyclophosphamide and mycophenolate mofetil as well as angiotensin converting enzyme inhibitors, especially prior to initiation of dialysis, can also contribute to anemia [30].

\section{Investigations for anemia}

The diagnosis of anemia and the determination of etiology should be made using a systematic approach utilizing both clinical and laboratory investigations (Table 3). A detailed history and physical examination including a family history, is invaluable for all patients. In terms of laboratory investigations, the NKF-DOQI guidelines recommend the following tests: complete blood count, including serum hemoglobin, mean corpuscular hemoglobin, mean corpuscular volume, mean corpuscular hemoglobin concentration, white blood cell count, differential count and platelet count [7]. Red blood cell indices on peripheral blood smears, especially mean corpuscular volume, can be useful in determining the etiology of anemia. Hypochromic microcytic erthryocytes with pencil cells is the classic presentation of iron deficiency anemia on a blood smear. However, CKD patients may have a normochromic and normocytic anemia [31]. NKF-KDOQI guidelines also recommend that reticulocyte counts should be obtained to measure the bone marrow response to anemia [7]. Furthermore, hemoglobin electrophoresis can detect the presence of concomitant hemoglobinopathies. A bone marrow examination is indicated when the etiology of the anemia cannot be determined after the clinician has performed a careful history, physical examination and a thorough analytical investigation of a peripheral blood sample. In HD patients, additional tests, including stool occult blood, serum aluminum and investigations for hemolysis, may be useful for delineating the cause of the anemia [19, 27].

Hematocrit is less reliable clinically, and this measure is affected by body temperature, body water, hyperglycemia and storage time prior to analysis [32, 33]. For hemoglobin measurements, the timing of measurements is also important. For example, in HD patients, although pre-dialysis hemoglobin levels are commonly used, it is not certain 
Table 3 The clinical and laboratory investigations recommended for evaluating anemia in pediatric patients with chronic kidney disease (CKD)

\begin{tabular}{l}
\hline Investigations \\
\hline Clinical \\
Review of medical history, including family history \\
Physical examination \\
Review of medication list \\
Determination of compliance with treatment \\
Initial investigations \\
Hemoglobin \\
Hematocrit \\
White blood cell count \\
-Differential count \\
Platelet count \\
Red blood cell indices \\
-Mean corpuscular hemoglobin \\
-Mean corpuscular volume \\
-Mean corpuscular hemoglobin concentration \\
Absolute reticulocyte count \\
Serum iron, ferritin and transferrin \\
Additional Investigations as indicated: \\
Hemoglobin electrophoresis \\
Assessment of occult blood loss \\
Serum folate, vitamin B12 \\
Serum parathyroid hormone \\
Assessment of hemolysis \\
Serum aluminum \\
Bone marrow examination \\
\hline
\end{tabular}

whether a pre-dialysis sample is appropriate when the patients have relative water excess. Post-dialysis samples usually demonstrate higher hemoglobin values that may be exaggerated if an inadequate time interval has been allotted for equilibration of fluid compartments post-dialysis.

The assessment of iron stores is essential to an evaluation of anemia. A number of laboratory measures are used to assess absolute and functional iron deficiency, including serum iron, ferritin and transferrin. NKF-KDOQI guidelines for the evaluation of anemia in children with CKD recommend measurements of serum ferritin and serum transferrin saturation (TSAT) [7].

The ideal iron measures will ensure that the treatment will provide consistent hemoglobin levels while avoiding excessive doses of iron and EPO. Serum iron is used as a measure of the amount of transferrin-bound iron in circulation [10]. Serum transferrin, a protein-based receptor for circulating iron, is an indicator of total iron binding capacity, but there is a diurnal fluctuation in its level and it is affected by nutritional status [34]. Serum ferritin indicates the level of stored iron; however, ferritin is an acute phase reactant and its level is less reliable in CKD patients. Therefore, no single measure accurately measures iron deficiency. Fishbane et al. studied 47 adult patients with baseline serum ferritin levels of less than $600 \mathrm{ng} / \mathrm{mL}$ who were treated with intravenous (IV) iron dextran. Patients whose hematocrit increased by $5 \%$ or who had a $10 \%$ decrease in their EPO dose over 2 months were classified as having an iron deficiency. These researchers found that serum ferritin levels of less than $150 \mathrm{ng} / \mathrm{mL}$ had a sensitivity and specificity of 71 and $69 \%$, respectively, and that transferrin saturations of less than $21 \%$ had a sensitivity and specificity of 81 and $63 \%$, respectively [35].

The most accepted method of determining iron status in pediatric patients is the TSAT, which is calculated by dividing serum iron by total iron binding capacity and multiplying by 100 . Total iron binding capacity is an indirect measure of the concentration of transferrin and is derived by multiplying the serum transferrin value by 1.4 [36]. A pediatric study of 160 patients on HD suggested that a TSAT of less than $20 \%$ is a significant predictor of iron deficiency [37].

There are several new methods available for assessing iron stores. These assays are important analytical tools in the presence of a functional iron deficiency where there is an adequate amount of stored iron but an impairment exists in the release of iron from these body stores. The percentage of circulating hypochromic red blood cells (PHRC) and the reticulocyte hemoglobin content $(\mathrm{CHr})$ are two such measures [36]. Many institutions may lack the necessary technology to measure PHRC. In terms of $\mathrm{CHr}$, there is no clear consensus on precisely what is the proper cut-off, and this measure is not used routinely in clinical practice. Additional tests described in the literature but not recommended for use are the measurement of zinc protoporphyrin (ZPP) and the serum soluble transferrin receptor assays [36]. Zinc replaces iron in protoporphyrin IX to form ZPP under conditions of iron deficiency [38]. ZPP is a measure of iron availability and stores; however, it is considered to be an inferior measure. The soluble transferrin receptor assay indicates the number of erythroblasts in the bone marrow and total erythroid activity. It has not been shown to be useful in CKD patients and is more costly $[39,40]$. All of these tests have not been examined fully in the pediatric CKD population and are limited to the research realm.

\section{Management of anemia}

\section{Prevention}

Anemia can develop during any stage of CKD in children and remains widely prevalent among the pediatric CKD population [6]. Therefore, the key to managing CKD in children may be to prevent anemia and to improve anemia management during all stages of CKD. Primary prevention 
measures for the development of anemia in children presenting with early stages of CKD need to be developed by means of systematic research. The current NKF-KDOQI guidelines recommend that hemoglobin be measured annually - at a very minimum - to screen for anemia [7]. In both dialysis and non-dialysis CKD patients, judicious use of blood tests and the early institution of therapy is important to prevent the progression and prolongation of anemia.

\section{Erythropoietin}

Soon after the development of recombinant human EPO, clinical trials confirmed the short-term efficacy of EPO for treating anemia associated with severe kidney disease predialysis and HD [41, 42]. These early studies used doses of EPO which varied from as little as $3 \mathrm{U} / \mathrm{kg}$ three times per week to as much as $150 \mathrm{U} / \mathrm{kg}$ three times per week. The development or aggravation of hypertension was noted in several patients, and Casati et al. reported the clotting of arteriovenous fistulae in two patients and a cerebral ischemic lesion in one patient from among the 14 patients treated with EPO [43].

The first reports of EPO use in children described five patients on continuous cycling peritoneal dialysis (CCPD) who received $150 \mathrm{U} / \mathrm{kg}$ three times per week; this resulted in the successful treatment of anemia, although hypertension was exacerbated in three of the patients [44]. Once the target hemoglobin level was achieved, these researchers reported that the treatment of anemia could be maintained with a dosage once weekly [44]. A larger patient group of 14 children on CCPD were described in a subsequent study in Germany. These patients received an initial EPO dose of $300 \mathrm{U} / \mathrm{kg}$ once weekly, which was adjusted downwards to a maintenance dose of approximately $100 \mathrm{U} / \mathrm{kg}$ once per week [45]. Again, the only side effect reported was hypertension. Following publication of these studies, EPO became the standard treatment for renal anemia in childhood and was prescribed at a dose of approximately $150 \mathrm{U} / \mathrm{kg}$ per week in clinical practice, divided into three doses per week. More recently, Provenzano et al. reported that for pre-dialysis adult patients, hemoglobin $>110 \mathrm{~g} / \mathrm{L}$ could be maintained by $90 \%$ of patients dosed every 1 or 2 weeks, and by three-quarters of patients dosed every 3 or 4 weeks [46].

Observational data from the North American Pediatric Renal Transplant Cooperative Study (NAPRTCS) 2004 registry report shows that younger children tend to require higher doses of EPO. Infants were shown to require the highest dose, ranging from 275 to $350 \mathrm{U} / \mathrm{kg}$ per week, while children older than 6 years of age required between 200 and $250 \mathrm{U} / \mathrm{kg}$ per week [47]. These apparent differences in the dosing of EPO among children of different age groups may be related to an increased presence of nonhematopoietic binding sites of EPO in younger children that may lead to increased clearance [48]. The requirement for EPO dosing also varies with modality of dialysis. PD patients tend to require less EPO (200-250 U/kg per week) than HD patients, who require $250-300 \mathrm{U} / \mathrm{kg}$ per week. The differences between dosing according to dialysis modality seem to dissipate at 30 months of follow-up. Most PD patients are reported to have received subcutaneous administration, whereas most HD patients received EPO via the IV route [47]. Dosing adjustments for EPO should be made cautiously using best clinical experience, always taking into consideration the duration of action of the EPO product prescribed. A dose increase or decrease of approximately $20 \%$ may be instituted in an attempt to maintain the hemoglobin at the target recommendations.

\section{Darbepoetin}

In 1999, MacDougall described the pharmacokinetics of darbepoetin alfa, a molecule with one amino acid substitution and two additional carbohydrate sites relative to EPO [49]. It was hoped that the additional glycosylation would extend the half-life of EPO. When tested in 11 stable PD patients, the mean terminal half-life for IV darbepoetin was threefold longer than for IV EPO (25.3 vs. $8.5 \mathrm{~h}$ ) [49]. Studies in children similarly showed that the half-life of darbepoetin alfa in children was 22.1 and $42.8 \mathrm{~h}$ following IV or subcutaneous administration, which again was much longer than that of EPO [50]. It was presumed that the extended half-life of darbepoetin alfa would allow for an extended period between individual doses. A subsequent randomized controlled trial demonstrated that darbepoetin alfa administered IV once weekly was equally effective for controlling anemia in HD patients as IV EPO administered three times per week [51]. Similarly, in a multicenter randomized open label study of pre-dialysis patients, darbepoetin, administered once weekly was again shown to be as effective as EPO administered twice weekly [52].

The first report of darbepoetin use in pediatric end-stage renal disease described seven children, aged $11.5 \pm 3$ years who received darbepoetin at a mean starting dose of $1.6 \mu \mathrm{g} / \mathrm{kg}$ IV once weekly [53]. The dose of darbepoetin reached a mean steady state value of $0.5 \mu \mathrm{g} / \mathrm{kg}$ per week by 3 months, with satisfactory hemoglobin values of $118 \mathrm{~g} / \mathrm{L}$. One patient had persistent thrombocytosis, while hypertension was seen in two patients when the hemoglobin was greater than $130 \mathrm{~g} / \mathrm{L}$. Our own subsequent experience in 33 children, including pre-dialysis, HD, and PD populations, confirmed the efficacy of darbepoetin [54]. A mean hemoglobin level of $114 \mathrm{~g} / \mathrm{L}$ was recorded between 20 and 28 weeks, and $91 \%$ of the patients had a hemoglobin value of greater than $100 \mathrm{~g} / \mathrm{L}$ during the same time interval. We also found that an 
exacerbation of hypertension associated with hemoglobin values greater than $130 \mathrm{~g} / \mathrm{L}$ and an occasional thrombocytosis were the only complications. Our study did not restrict patients to once weekly dosing, and almost $90 \%$ of our patients were prescribed darbepoetin less often than once weekly by week 28 of the study. However, two problems were noted with darbepoetin: (1) eight of the 14 patients who were asked to describe the pain of darbepoetin injection reported that it was worse than what they had previously experienced with EPO; (2) because darbepoetin comes in pre-filled unidose syringes at $10-\mu \mathrm{g}$ increments, dosing is not convenient for small infants, and the administration of a partial syringe is not recommended because of potential inconsistent mixing of the active ingredient within the syringe. Based on these results, we reviewed our experience in six infants weighing $<8 \mathrm{~kg}$. The drug was administered after partial withdrawal of the pre-filled syringe into a calibrated 1-ml syringe prior to injection. Three medically stable infants responded very well to darbepoetin at a dose of only $0.25 \mu \mathrm{g} / \mathrm{kg}$ per week. In three infants who were medically unstable and continually hospitalized for various invasive procedures, it was difficult to determine the efficacy of darbepoetin [55].

Overall, therefore, it appears that darbepoetin and EPO are equally efficacious for treating anemia associated with $\mathrm{CKD}$, and the extended half-life of darbepoetin does provide an advantage by allowing less frequent dosing. Nonetheless, provision of the drug in pre-filled unidose syringes does not allow for small incremental dosing and is therefore not childfriendly. The issue of pain at the injection site may not be a feature of darbepoetin outside Canada, where the product may be manufactured differently.

Pure red cell aplasia and erythropoietic agents

Approximately one half of all cases of pure red cell aplasia (PRCA) are idiopathic, and this disorder has also been associated with cases of systemic lupus erythematosus and with infection due to Parvovirus B19. In 2002, a report was published on the occurrence of pure red cell aplasia and anti-EPO antibodies in patients treated with EPO [56]. Most of these patients received Eprex, an epoetin alfa product marketed outside of the United States [57]. In a review of 170 of 200 patients for whom there was follow-up information on PRCA for at least 3 months, 37\% recovered hematologically, although the vast majority of these patients required immunosuppressive therapy [53]. The epidemiologic data confirmed that PRCA was much more likely with subcutaneous administration of EPO than with IV administration, with the majority of cases occurring with EPO alfa produced by Ortho Biotech, although 11 cases were also reported following the use of EPO-Beta, manufactured by Roche and eight cases following the use of EPO Alfa produced by Amgen and marketed in the United States [58]. Finally, two cases of antibodymediated PRCA have also been reported with darbepoetin use. The overall incidence of PRCA following the administration of Eprex has dropped greatly since 2004, when the method by which Eprex is stored and reconstituted was changed.

\section{Iron}

Iron repletion and maintenance is the second pillar of anemia management in kidney disease. Iron-deficient patients are also known to require higher doses of EPO to maintain target hemoglobin levels [59]. The current NKFKDOQI recommendation for targets of iron therapy is to maintain serum ferritin at $>100 \mathrm{ng} / \mathrm{mL}$ and TSAT at $>20 \%$ in pediatric $\mathrm{HD}, \mathrm{PD}$ and non-dialysis CKD patients. It is important to use these targets conscientiously and to be aware of 'functional' iron deficiency.

Oral iron supplements, though cheap, are often insufficient to maintain iron stores, especially in HD patients, due to excessive blood loss, poor absorption, poor compliance with medications and gastrointestinal side effects. In addition, timing of the oral iron dose may be difficult, as it needs to be separated from phosphate binders and antacids [60]. Nevertheless, non-dialysis CKD patients or PD patients can be managed with oral iron. The current NKF-KDOQI guidelines recommend oral iron therapy to be given in doses ranging from $2-3 \mathrm{mg} / \mathrm{kg}$ up to $6 \mathrm{mg} / \mathrm{kg}$ of elemental iron per day in two to three divided doses per day [7]. Oral iron should be taken $2 \mathrm{~h}$ before or $1 \mathrm{~h}$ after all calcium-containing binders and food in order to maximize gastrointestinal absorption. Absorption may also be reduced in patients on proton pump inhibitors (e.g. omeprazole) [61].

HD patients have many opportunities to experience iron loss, including excessive blood sampling, loss of blood through the dialyzer and tubing. IV doses of iron can be easily given to CKD patients who are on HD through the central venous access. Maintenance therapy aims to provide $1-2 \mathrm{mg} / \mathrm{kg}$ of elemental iron per week to achieve a TSAT between 20 and $50 \%$ and serum ferritin levels of 100 $800 \mathrm{ng} / \mathrm{mL}$ [7]. Higher doses of intermittent IV iron are usually given less frequently to non-dialysis CKD patients or PD patients. The risks of short-term and long-term toxicities of higher doses of IV iron need to be studied.

Several clinical trials have recently examined the role of IV iron supplementation in pediatric patients. One study in 2003 included 40 pediatric HD patients who had anemia with a serum ferritin of $<100 \mu \mathrm{g} / \mathrm{L}$ and a TSAT of $<20 \%$. Laboratory tests, including those for hemoglobin, TSAT and ferritin, were performed monthly over a 6-month period. Patients were randomized into two groups, with 
the first group having iron dosed according to ferritin levels and the control group receiving ten dose courses according to body weight $(<10 \mathrm{~kg}, 25 \mathrm{mg} /$ dose $; 10-20 \mathrm{~kg}, 50 \mathrm{mg} /$ dose; $>20 \mathrm{~kg}, 100 \mathrm{mg} / \mathrm{dose})$. There were a large number of drop-outs due to iron overload in this study, and only few patients actually completed the intended protocol. However, both treatment arms were able to raise hemoglobin levels to $10 \mathrm{~g} / \mathrm{dL}$ after 3 months [62].

Warady et al. examined the efficacy and safety of maintenance IV iron versus oral iron in HD patients in 2004 [63]. This study was a multicenter, prospective, randomized controlled trial of 35 iron-replete pediatric HD patients with end stage renal disease. The patients were randomized to receive 12 weeks of maintenance IV iron dextran or daily oral iron therapy (4-6 mg/kg per day). The study showed that the IV iron group had statistically significant increased ferritin and also used less EPO. Overall, the results of this study suggest that intermittent IV or daily oral dosing of iron maintains iron stores in HD patients. Warady et al. also studied iron therapy using an IV sodium ferric gluconate complex (SFGC) in pediatric HD patients. Efficacy and safety profiles were similar for the two dose regimens tested $(1.5 \mathrm{mg} / \mathrm{kg}$ and $3.0 \mathrm{mg} / \mathrm{kg}$ administered sequentially in eight HD sessions). Sustained significant increases were noted in hemoglobin in both treatment doses compared to baseline at 2 and 4 weeks after cessation of treatment [64].

The IV iron formulations currently available include iron dextran, iron sucrose and sodium ferric gluconate. All IV iron formulations may be associated with adverse events, including immune-mediated reactions that may lead to anaphylaxis and the release of bioactive and partially unbound iron into the circulation by the iron agent, causing oxidative stress and hypotension. Anaphylaxis is more common in iron dextran formulations, while non-dextran forms of iron tend to have reactions associated with free iron release [65-68]. The IV SFGC formulation of iron has a better safety profile when compared to IV iron dextran: IV SFGC had an allergy reporting rate of 3.3 allergy episodes per million doses per year compared to 8.7 allergy episodes per million doses per year for iron dextran in the United States. The mortality rate is also significantly lower with SFGC use [69]. Warady et al. evaluated the safety of SFGC therapy among pediatric HD patients and reported four treatment-related adverse events, including mild nausea, diarrhea, vomiting and worsening of anemia in one patient. No anaphylactic reactions were reported in this study [64]. Morgan et al. evaluated iron sucrose maintenance therapy in a small observational study of pediatric HD patients. They did not find any adverse events among the patients treated with iron sucrose, although these results should be interpreted with caution due to the small sample size [22].
Adjunctive treatments for anemia

L-Carnitine Adjunctive treatment for anemia with L-carnitine is not routinely recommended. Only a very few small trials in children have examined the role of carnitine in improving anemia or effecting a change in the dose of EPO, and these did not demonstrate a clear benefit $[70,71]$.

Vitamin $C$ The role of supplemental vitamin $\mathrm{C}$ has been examined in adult HD patients with anemia, iron overload and elevated serum ferritin, and some studies have shown reduction in hyporesponsiveness to EPO or functional iron deficiency [72-74]. However, the long-term safety of administering IV vitamin $\mathrm{C}$ to $\mathrm{HD}$ patients is still undefined, with secondary oxalosis being the primary concern. The revised NKF-KDOQI guidelines do not recommend the use of vitamin $\mathrm{C}$ in children [7].

Folate The role of folate deficiency on chronic HD was examined in 15 subjects aged 8-20 years. In a 12-month crossover study where patients received no folate for 6 months and then $5 \mathrm{mg}$ of folate for the next 6 months, the researchers found that after folate use mean hemoglobin increased by $11.4 \%$ [75]. There is no specific recommendation regarding the routine use of folate in treatment of anemia in the new NKF-KDOQI guidelines for children.

\section{Clinical outcomes and benefits of therapy}

Anemia is associated with significant morbidity and mortality in patients with CKD. Complications related to anemia include kidney disease progression, cardiovascular disease, hospitalization, mortality, and an impaired quality of life.

Progression of kidney disease Irrespective of the underlying cause, the progression of kidney disease leads to obsolete or sclerotic glomeruli, tubular atrophy and interstitial fibrosis. Anemia and subsequent tissue hypoxia may contribute to this progression to end stage kidney disease. Hypoxia of tubular cells may lead to interstitial fibrosis, tubular damage and an increase in the extracellular matrix. Hypoxia also stimulates the release of cytokines promoting fibrosis. Therefore, the correction of anemia may lead to increased oxygen delivery to tubular cells, decrease tubular damage and protect against nephron loss induced by tubular injury [76].

Cardiovascular disease Ongoing chronic anemia will manifest clinically as tachycardia and shortness of breath on exertion, possibly progressing over time to cardiac dilata- 
tion, left ventricular hypertrophy or congestive heart failure. Mitsnefes et al. reported that pediatric patients with left ventricular hypertrophy had significantly lower hemoglobin values than those without left ventricular hypertrophy (hemoglobin: $9.5 \pm 1.8$ vs. $10.9 \pm 2.3 \mathrm{~g} / \mathrm{dL}$ ) [77].

Hospitalization and mortality Warady and Ho studied the NAPRTCS database to assess the association between anemia at 30 days post-initiation of dialysis and patient mortality. They demonstrated that anemia 30 days postinitiation of dialysis was associated with a relative risk of death of 1.52 (95\% confidence interval: $1.03-2.26)$ and that the presence of anemia was also related to an increased risk of hospitalization [78].

Quality of life In children with $\mathrm{CKD}$, the correction of anemia has been associated with an improvement in exercise capacity and quality of life. Morris et al. completed a single blind, placebo controlled crossover study in 11 children with end stage kidney disease to assess the clinical benefits of anemia correction. An increase in hemoglobin level was associated with an improvement in exercise tolerance, physical performance and school attendance [3]. The quality of life and its relationship to anemia have been examined in children with kidney disease, although many of the studies used non-validated instruments to measure this parameter. Nevertheless, Gerson et al. published a study on health-related quality of life in adolescent dialysis patients in which they had used a generic quality-of-life questionnaire completed by caregivers of 105 adolescents with NKF-KDOQI stages 1 to 5 CKD. These researchers found that anemic patients had a lower quality of life across all stages of CKD and that there was a strong dose response relationship between hemoglobin level and quality of life as measured using this particular questionnaire [79].

Higher hemoglobin targets for therapy NKF-KDOQI clinical practice guidelines for anemia in children with CKD recommend that the target hemoglobin level should be $11.0 \mathrm{~g} / \mathrm{dL}$ or greater. In contrast to the benefits achieved by maintaining hemoglobin above a minimum target level, there is insufficient evidence to support an upper limit of hemoglobin for therapy in children. Higher hemoglobin and hematocrit targets in adults have not shown any benefit in terms of decreasing cardiovascular mortality or left ventricular volume index. Besarab et al. published a randomized prospective open-label trial in which they compared the effects of normal $(42 \%)$ and lower $(30 \%)$ hematocrit values in patients with clinically evident congestive heart failure or ischemic heart disease on HD [80]. The study was stopped prematurely due to higher incidence of primary outcome rates (death or first non-fatal myocardial infarction). Although the results were not statistically significant, the risk ratio for the normal hematocrit group compared to lower hematocrit group was 1.3 (95\% confidence interval: $0.9-1.9$ ). In addition, the incidence of thrombosis of the vascular access sites was higher in the higher hematocrit group. These results should be viewed with caution in that they may not be generalizable to the pediatric population, as many CKD patients may not have clinically evident cardiovascular disease. A randomized double blind study conducted by Parfrey et al. comparing left ventricular volume index in early HD patients without symptomatic heart disease who were assigned to either low $(9.5-11.5 \mathrm{~g} / \mathrm{dL})$ or to higher $(13.5-14.5 \mathrm{~g} / \mathrm{dL})$ hemoglobin targets showed no difference in the primary outcome. Improvement in left ventricular dilatation was noted in some patients [81], while cerebrovascular events were higher in the higher hemoglobin target group. Improved SF-36 vitality scores were noted in the higher versus the lower group, suggesting an improvement in the quality of life. Therefore, there is lack of clear benefit in maintaining higher targets of hemoglobin among adult CKD patients. In children, the benefits of higher hemoglobin targets are unclear, especially the effects on quality of life and growth measurements.

\section{Summary}

In summary, the etiology and management of anemia is complex in children with CKD, with current management and therapeutic decisions guided by results of both adult and pediatric studies. EPO and IV iron therapy have revolutionized the treatment of anemia in children; however, anemia continues to be a very prevalent problem among pediatric CKD patients. Pediatric nephrologists are encouraged to use current clinical practice guidelines and best evidence in conjunction with their clinical experience to optimally manage patients with anemia.

Questions: (answers will appear following the reference list)

1. Reported side effects of erythropoietin therapy include:
a. Pure red cell aplasia
b. Hypertension
c. Thrombosis
d. All of the above

2. Iron supplements should not be taken together with:
a. Calcium containing binders
b. Vitamin $\mathrm{C}$
c. ACE inhibitors
d. Vitamin D

3. Pure red cell aplasia is more common in what form of erythropoietin administration: 

a. Intravenous
b. Subcutaneous
c. Intraperitoneal
d. Oral

4. Correction of anemia in children with chronic kidney disease has been associated with:
a. Improved exercise tolerance
b. Physical performance
c. School attendance
d. All of the above

5. Severe hyperparathyroidism can cause anemia in chronic kidney disease due to:
a. Adynamic bone disease
b. Osteodystrophy
c. Myelofibrosis
d. Hypercalcemia

\section{References}

1. Levin A, Thompson CR, Ethier J, Carlisle EJ, Tobe S, Mendelssohn D (1999) Left ventricular mass index increase in early renal disease: impact of decline in hemoglobin. Am J Kidney Dis 34:125-134

2. Morris KP, Skinner JR, Hunter S, Coulthard MG (1994) Cardiovascular abnormalities in end stage renal failure: the effect of anaemia or uraemia? Arch Dis Child 71:119-122

3. Morris KP, Sharp J, Watson S, Coulthard MG (1993) Non-cardiac benefits of human recombinant erythropoietin in end stage renal failure and anaemia. Arch Dis Child 69:580-586

4. Jabs K (1996) The effects of recombinant human erythropoietin on growth and nutritional status. Pediatr Nephrol 10:324-327

5. Chavers BM, Roberts TL, Herzog CA, Collins AJ, St Peter WL (2004) Prevalence of anemia in erythropoietin-treated pediatric as compared to adult chronic dialysis patients. Kidney Int 65:266-273

6. Wong H, Mylrea K, Feber J, Drukker A, Filler G (2006) Prevalence of complications in children with chronic kidney disease according to KDOQI. Kidney Int 70:585-590

7. K/DOQI; National Kidney Foundation (2006) III Clinical Practice Recommendations for Anemia in Chronic Kidney Disease in Children. Am J Kidney Dis 47(Suppl 3):S86-108

8. Behrman RE, Kliegman R, Jenson HB (2000) Nelson textbook of pediatrics, 16th edn. W.B. Saunders Company, Collingwood, Ontario

9. Beutler E, Waalen J (2006) The definition of anemia: what is the lower limit of normal of the blood hemoglobin concentration. Blood 107:1747-1750

10. Hollowell JG, Van Assendelft OW, Gunter EW, Lewis BG, Najjar M, Pfeiffer C (2005) Hematological and iron-related analytes reference data for persons aged 1 year and over: United States, 1988-1994. National Center for Health Statistics. Vital Health Stat 11:1-156

11. McGonigle RJ, Wallin JD, Shadduck RK, Fisher JW (1984) Erythropoietin deficiency and inhibition of erythropoiesis in renal insufficiency. Kidney Int 25:437-444

12. Eschbach JW, Egrie JC, Downing MR, Browne JK, Adamson JW (1987) Correction of the anemia of end-stage renal disease with recombinant human erythropoietin. Results of a combined phase I and II clinical trial. N Engl J Med 316:73-78

13. Jacobs K, Shoemaker C, Rudersdorf R, Neill SD, Kaufman RJ, Mufson A, Seehra J, Jones SS, Hewick R, Fritsch EF, Kawakita M, Shimizu T, Miyake T (1985) Isolation and characterization of genomic cDNA clones of human erythropoietin. Nature 313: $806-810$

14. Lin FK, Suggs S, Lin CH, Browne JK, Smailing R, Egric JC, Chen KK, Fox GM, Martin F, Stabinsky Z, Badrawi SM, Lai PH, Goldwasser E (1985) Cloning and expression of the human erythropoietin gene. Proc Natl Acad Sci USA 82:7580-7584

15. Fisher JW (2003) Erythropoietin: physiology and pharmacology update. Exp Biol Med 228:1-14

16. Koury MJ, Bondurant MC (1992) The molecular mechanism of molecular erythropoietin production. Eur J Biochem 210:649-666

17. Donnelly S (2001) Why is erythropoietin made in the kidney? The kidney functions as a critmeter. Am J Kidney Dis 38:415-425

18. Besarab A, Frinak S, Yee J (1999) An indistinct balance: the safety and efficacy of parenteral iron therapy. J Am Soc Nephrol 10:2029-2043

19. Ly J, Marticorena R, Donnelly S (2004) Red blood cell survival in chronic renal failure. Am J Kidney Dis 44:715-719

20. Muller-Wiefel DE, Sinn H, Gilli G, Scharer K (1977) Hemolysis and blood loss in children with chronic renal failure. Clin Nephrol 8:481-486

21. Gillespie RS, Wolf FM (2004) Iron therapy in pediatric hemodialysis patients: a meta-analysis. Pediatr Nephrol 19:662666

22. Morgan HE, Gautam M, Geary DF (2001) Maintenance intravenous iron therapy in pediatric hemodialysis patients. Pediatr Nephrol 16:779-783

23. Andrews NC (1999) Disorders of iron metabolism. N Engl J Med 341:1986-1995

24. Macdougall IC, Cooper AC (2002) Erythropoietin resistance: the role of inflammation and pro-inflammatory cytokines. Nephrol Dial Transplant 17[Suppl 11]:39-43

25. Pereira BJ (1995) Balance between pro-inflammatory cytokines and their specific inhibitors in patients on dialysis. Nephrol Dial Transplant 10[Suppl 7]:27-32

26. Nomura S, Ogawa Y, Osawa G, Katagiri M, Harada T, Nagahana H (1996) Myelofibrosis secondary to renal osteodystrophy. Nephron 72:683-687

27. Rosenlof K, Fyhrquist F, Tenhunen R (1990) Erythropoietin, aluminium, and anaemia in patients on hemodialysis. Lancet 335:247-249

28. Roger SD, Macdougall IC, Thuraisingham RC, Raine AE (1991) Erythropoietin in anemia of renal failure in sickle cell disease. N Engl J Med 325:1175-1176

29. Cheng IK, Lu HB, Wei DC, Cheng SW, Chan CY, Lee FC (1993) Influence of thalassemia on the response to recombinant human erythropoietin in dialysis patients. Am J Nephrol 13:142-148

30. Hess E, Sperschneider H, Stein G (1996) Do ACE inhibitors influence the dose of human recombinant erythropoietin in dialysis patients? Nephrol Dial Transplant 11:749-751

31. Lu R, Foerster J, Lukens J, Paraskevas F, Greer JP (1999) Wintrobe's clinical hematology, 10th edn. Lippincott Williams and Wilkins, Philadelphia

32. Henry JB (1996) Methods hematology: basic methodology in clinical diagnosis and management by laboratory methods, 19th edn. Saunders, Philadelphia

33. Holt JT, DeWandler MJ, Aevan DA (1982) Spurious elevation of electronically determined mean corpuscular volume and hematocrit caused by hyperglycemia. Am J Clin Pathol 77:561-567

34. Adamson JW (1999) Normal iron physiology. Semin Dialysis $12: 219-223$ 
35. Fishbane S, Kowalski EA, Imbriano LJ, Maesaka JK (1996) The evaluation of iron status in hemodialysis patients. J Am Soc Nephrol 7:2654-2657

36. Mittal S, Maesaka JK, Fishbane S (1999) Diagnosis of iron deficiency in end stage renal disease. Semin Dial 12:231-234

37. Frankenfield DL, Neu AM, Warady BA, Fivush BA, Johnson CA, Brem AS (2003) Anemia in pediatric hemodialysis patients: results from the 2001 ESRD Clinical Performance Measures Project. Kidney Int 64:1120-1124

38. Braun J (1999) Erythrocyte zinc protoporphyrin. Kidney Int 55 [Suppl 69]:S57-S60

39. Thomas C, Thomas L (2002) Biochemical markers and hematologic indices in the diagnosis of functional iron deficiency. Clin Chem 48:1066-1076

40. Chiang WC, Tsai TJ, Chen YM, Lin SL, Hsieh BS (2002) Serum soluble transferrin receptor reflects erythropoiesis but not iron availability in erythropoietin-treated chronic hemodialysis patients. Clin Nephrol 58:363-369

41. Winearls CG, Oliver DO, Pippard MJ, Reid C, Downing MR, Coates PM (1986) Effective human erythropoietin derived from recombinant DNA on the anemia of patients maintained by chronic hemodialysis. Lancet 2:1175-1178

42. Eschbach JW, Kelly MR, Haley NR, Abels RI, Adamson JW (1989) Treatment of the anemia of progressive renal failure with recombinant human erythropoietin. N Engl J Med 321:158-163

43. Casati S, Passerini P, Campise MR, Graziani G, Cesana E, Ponticelli C (1987) Benefits and risks of protracted treatment with human recombinant erythropoietin in patients having hemodialysis. N Engl J Med 295:1017-1020

44. Sinai-Trieman L, Salusky IB, Fine RN (1989) Use of subcutaneous recombinant human erythropoietin in children undergoing continuous cycling peritoneal dialysis. J Pediatr 114:550-554

45. Offner G, Hoyer PF, Latta K, Winkler L, Brodehl J, Scigalla P (1990) One year's experience with recombinant erythropoietin in children undergoing continuous ambulatory or cycling peritoneal dialysis. Pediatr Nephrol 5:498-500

46. Provenzano R, Bhaduri S, Singh AK (2005) Extended epoetin alfa dosing as maintenance treatment for the anemia of chronic kidney disease: the prompt study. Clin Nephrol 2:113-123

47. North American Pediatric Renal Transplant Cooperative Study Registry Report (2004) https://web.emmes.com/study/ped/annlrept/ annlrept.html

48. Port RE, Kiepe D, Van Guilder M, Jelliffe RW, Mehls O (2004) Recombinant human erythropoietin for the treatment of renal anaemia in children: no justification for bodyweight-adjusted dosage. Clin Pharmacokinet 43:57-70

49. MacDougall IC, Gray SJ, Elston O, Breen C, Jenkins B, Browne J (1999) Pharmacokinetics of novel erythropoesis-stimulating protein compared with epoetin alfa in dialysis patients. J Am Soc Nephrol 10:2392-2395

50. Lerner G, Kale AS, Warady BA, Jabs K, Bunchman TE, Heatherington A (2002) Pharmacokinetics of darbepoetin alfa in pediatric patients with chronic kidney disease. Pediatr Nephrol 11:933-937

51. Nissenson AR, Swan SK, Lindberg JS, Soroka SD, Beatey R, Wang C (2002) Randomized control trial of Darbepoetin Alfa for the treatment of anemia in hemodialysis patients. Am J Kidney Dis $40: 110-118$

52. Locatelli F, Olivares J, Walker R, Wilkie M, Jenkins B, Dewey C, Gray SJ (2001) Novel erythropoesis-stimulating protein for treatment of anemia in chronic renal insufficiency. Kidney Int 60:741-747

53. DePalo P, Giordanno M, Palumbo F, Bellantuono R, Messina G, Colella V, Caringella AD (2004) Clinical experience with
Darbepoetin Alfa (NESP) in children undergoing hemodialysis. Pediatr Nephrol 3:337-340

54. Geary DF, Keating LE, Vigneux A, Stevens D, Hébert D, Harvey EA (2005) Darbepoetin Alfa (Aranesp) in children with chronic renal failure. Kidney Int 4:1759-1765

55. Durkan AM, Keating LE, Vigneux A, Geary DF (2006) The use of Darbepoetin in infants with chronic renal impairment. Pediatr Nephrol 5:694-697

56. Casadevall N, Nataf J, Viron B, Colta A, Kiladjian JJ, MartinDupont P, Michaud P, Papo T, Ugo V, Teyssandier I, Varet B, Mayeux P (2002) Pure red cell aplasia and anti-erythropoietin antibodies in patients treated with recombinant erythropoietin. $\mathrm{N}$ Engl J Med 346:46-475

57. Bennett CL, Cournoyer D, Carson KR, Rossert J, Luminari S, Evens AM (2005) Long term outcome of individuals with pure red cell aplasia and antierythropoietin antibodies in patients treated with recombinant epoetin; a follow-up report from the Research on Adverse Drug Events and Reports (RADAR) Project. Blood 106:3343-3347

58. Casadeall N, Eckardt KU, Rossert J (2005) Epoetin induced autoimmune pure red cell aplasia. J Am Soc Nephrol 16:S67-S69

59. Fishbane S, Maesaka JK (1997) Iron management in end-stage renal disease. Am J Kidney Dis 29:319-333

60. Fishbane S (1998) Iron treatment: impact of safety issues. Am J Kidney Dis 32[Suppl 4]:S152-S156

61. Jensen RT (2006) Consquences of long-term proton pump blockage: insights from studies of patients with gastrinomas. Basic Clin Pharmacol Toxicol 98:4-19

62. Ruiz-Jaramillo Mde L, Guizar-Mendoza JM, Gutierrez-Navarro Mde J, Dubey-Ortega LA, Amador-Licona N (2004) Intermittent versus maintenance iron therapy in children on hemodialysis: a randomized study. Pediatr Nephrol 19:77-81

63. Warady BA, Kausz A, Lerner G, Brewer ED, Chadha V, Brugnara (2004) Iron therapy in the pediatric hemodialysis population. Pediatr Nephrol 19:655-661

64. Warady BA, Zobrist RH, Wu J, Finan E (2005) Ferrlecit Pediatric Study Group. Sodium ferric gluconate complex therapy in anemic children on hemodialysis. Pediatr Nephrol 20:1320-1327

65. Novey HS, Pahl M, Haydik I, Vaziri ND (1994) Immunologic studies of anaphylaxis to iron dextran in patients on renal dialysis. Ann Allergy 72:224-228

66. Agarwal R, Vasvada N, Sachs NG, Chase S (2004) Oxidative stress and renal injury with intravenous iron in patients with chronic kidney disease. Kidney Int 65:2279-2289

67. Fletes R, Lazarus M, Gage J, Chertow GM (2001) Suspected iron dextran-related adverse drug events in hemodialysis patients. Am J Kidney Dis 37:743-749

68. Fishbane S, Ungureanu VD, Maesaka JK, Kaupke CJ, Lim V, Wish J (1996) The safety of intravenous iron dextran in hemodialysis patients. Am J Kidney Dis 28:529-534

69. Faich G, Strobos J (1999) Sodium ferric gluconate complex in sucrose: saferintravenous iron therapy than iron dextrans. Am J Kidney Dis 33:464-470

70. Berard E, Iordache A (1992) Effect of low doses of Lcarnitine on the response to recombinant human erythropoietin in hemodialyzed children: about two cases. Nephron 62: 368-369

71. Lilien MR, Duran M, Quak JM, Frankhuisen JJ, Schroder CH (2000) Oral L-carnitine does not decrease erythropoietin requirement in pediatric dialysis. Pediatr Nephrol 15:17-20

72. Gastaldello K, Vereerstraeten A, Nzame-Nze T, Vanherweghem JL, Tielemans C (1995) Resistance to erythro- poietin in ironoverloaded haemodialysis patients can be overcome by ascorbic acid administration. Nephrol Dial Transplant 10 [Suppl 6]:44-47 
73. Deira J, Diego J, Martinez R, Oyarbide A, Gonzalez A, Diaz H, Grande J (2003) Comparative study of intravenous ascorbic acid versus low-dose desferroxamine in patients on hemodialysis with hyperferritinemia. J Nephrol 16:703-709

74. Keven K, Kutlay S, Nergizoglu G, Erturk S (2003) Randomized, crossover study of the effect of vitamin $\mathrm{C}$ on EPO response in hemodialysis patients. Am J Kidney Dis 41:1233-1239

75. Bamgbola OF, Kaskel F (2005) Role of folate deficiency on erythropoietin resistance in pediatric and adolescent patients on chronic dialysis. Pediatr Nephrol 20:1622-1629

76. Rossert J, Fouqueray B, Boffa JJ (2003) Anemia management and the delay of chronic renal failure progression. J Am Soc Nephrol 14[Suppl 2]:S173-S177

77. Mitsnefes MM, Daniels SR, Schwartz SM, Meyer RA, Khoury P, Strife CF (2000) Severe left ventricular hypertrophy in pediatric dialysis: prevalence and predictors. Pediatr Nephrol 14:898-902

78. Warady BA, Ho M (2003) Morbidity and mortality in children with anemia at initiation of dialysis. Pediatr Nephrol 18:1055-1062

79. Gerson A, Hwang W, Fiorenza J, Barth K, Kaskel F, Weiss L, Zelikovsky N (2004) Anemia and health-related quality of life in adolescents with chronic kidney disease. Am J Kidney Dis 44:1017-1023

80. Besarab A, Bolton WK, Browne JK, Egrie JC, Nissenson AR, Okamoto DM, Schwab SJ, Goodkin DA (1998) The effects of normal as compared with low hematocrit values in patients with cardiac disease who are receiving hemodialysis and epoetin. $\mathrm{N}$ Eng J Med 339:584-590

81. Parfrey PS, Foley RN, Wittreich BH, Sullivan DJ, Zagari MJ, Frei D (2005) Double-blind comparison of full and partial anemia correction in incident hemodialysis patients without symptomatic heart disease. J Am Soc Nephrol 16:2180-2189

\section{Answers:}

1. d. All of the above

2. a. Calcium containing binders

3. b. Subcutaneous

4. d. All of the above

5. c. Myelofibrosis 